\title{
Fruit quality attributes of low chilling requirement 'Snowchaser' blueberry cultivated in Brazil
}

\author{
Isabela Maria Jimenes ${ }^{1}$, Simone Rodrigues da Silva ${ }^{2}$, \\ Jaqueline Visioni Tezotto-Uliana ${ }^{3}$, Tatiana Cantuarias-Avilés ${ }^{4}$
}

\begin{abstract}
In Brazil there are still few studies on the post-harvest quality of low-chill blueberry cultivars, which have been recently introduced in the country. 'Snowchaser' blueberries were evaluated during a six-day storage period regarding fruit physical and chemical properties, and its antioxidant capacity. During fruit storage there was an increased weight loss and maintenance of some skin color properties such as luminosity $\left(\mathrm{L}^{*}\right)$ and $\mathrm{b}^{*}$, whereas the values of parameter $\mathrm{a}^{*}$ decreased and chroma (C) values increased. The levels of anthocyanins and flavonoids in the pulp increased, as well as the antioxidant activity. Maximum fruit shelf life at room temperature was six days without reduction on the antioxidant activity along the period, which is beneficial to consumers' health.

Index terms: Vaccinium corymbosum, weight loss, color, anthocyanins, flavonoids, antioxidant activity.

\section{Atributos de qualidade em frutos de mirtileiro 'Snowchaser' de baixa exigência em frio cultivados no Brasil}

Corresponding author: E-mail: srsilva@usp.br Received: October 10, 2016. Accepted : March 27, 2017.
Copyright: All the contents of this journal, except where otherwise noted, is licensed under a Creative Commons Attribution License.
Resumo - Há poucos estudos sobre a qualidade pós-colheita de cultivares de mirtilos de baixa exigência em frio hibernal, recentemente introduzidas no Brasil. Frutos de mirtileiro 'Snowchaser' foram avaliados quanto às propriedades físicas e químicas e também com relação à atividade antioxidante, durante 6 dias de armazenamento. Houve aumento da perda de massa e manutenção das variáveis colorimétricas de luminosidade $\left(\mathrm{L}^{*}\right)$ e $\left(\mathrm{b}^{*}\right)$, enquanto os valores da variável a* diminuíram e os de croma aumentaram. Os teores de antocianinas e flavonoides aumentaram, assim como a atividade antioxidante. O período máximo de conservação dos frutos em temperatura ambiente foi de 6 dias, sem redução da atividade antioxidante ao longo do período, o que é benéfico para a saúde dos consumidores.

Termos para indexação: Vaccinium corymbosum, perda de massa, coloração, antocianinas, flavonoides, atividade antioxidante.

\section{(cc) EY}

${ }^{1}$ Master Degree Student in Plant Science, Escola Superior de Agricultura "Luiz de Queiroz”, Universidade de São Paulo, Piracicaba-SP. Brazil. E-mail: isabela. jimenes@usp.br

${ }^{2}$ Associated Professor, Escola Superior de Agricultura “Luiz de Queiroz”, Universidade de São Paulo, Piracicaba-SP. Brazil. E-mail: srsilva@usp.br

${ }^{3}$ PhD Student in Plant Science, Escola Superior de Agricultura "Luiz de Queiroz", Universidade de São Paulo, Piracicaba-SP. Brazil. E-mail: jaqueline.tezotto@ usp.br

${ }^{4}$ Postdoctoral Researcher in Plant Science, Escola Superior de Agricultura "Luiz de Queiroz", Universidade de São Paulo, Piracicaba-SP. Brazil. E-mail: tatiana. cantuarias@gmail.com 
The pleasant flavor and the presence of considerable amounts of bioactive components, such as polyphenols, are responsible for the increase in blueberry fruit consumption (PATEL, 2014; LIM, 2012). Phenolic compounds are present in large amounts in blueberries, and may capture free radicals, inactivating them and preventing some forms of cancer, cardiovascular and neurodegenerative diseases, as well as certain inflammatory processes, among other diseases, therefore being defined as antioxidants compounds (CONCENÇO et al., 2014).

Anthocyanins belong to this group of compounds and their antioxidant activity can be understood as the ability to inhibit oxidative degradation processes, due to their composition and chemical properties, as well as their bioavailability and resulting biological activity (CONCENÇO et al., 2014). Anthocyanin content in the fruits may vary depending on genus, species and cultivar, and their activity is influenced by environmental factors, cultural traits (RODRIGUES et al., 2011) and storage conditions.

There are still few studies on post-harvest quality of blueberry cultivars with low chill demand, which have been recently introduced in Brazil (CANTUARIASAVILÉS et al., 2014). Therefore, new research on this subject may reveal technologies for quality maintenance of these fruits. The 'Snowchaser' blueberry cultivar belongs to the earliest Southern Highbush group and has low chilling requirements, with fruit being harvested between April-May in California and North Florida. In Florida, where it was developed, this cultivar grows vigorously, and has a spreading habit, with good fruit yield and quality. Fruits are is medium-sized, with bright blue color and suitable firmness (LYRENE, 2008). The aim of this study was to evaluate the physical and chemical properties and the antioxidant capacity of 'Snowchaser' blueberries under room temperature storage.

Fruit of this cultivar were harvested in January 2015 in a commercial blueberry grove located in Piracicaba, Brazil, and were immediately transported to the Laboratory of Physiology and Biochemical Postharvest, at the Luiz de Queiroz College of Agriculture - Esalq/ USP, where they were stored at room temperature $\left(22^{\circ} \mathrm{C}\right.$ and $60 \%$ of RH), for 6 days.

Fruit fresh weight loss (\%) was calculated from the difference between the initial mass and that verified after each day of evaluation. Blueberry fruit skin color was assessed with a digital colorimeter (Konica Minolta Inc., Japan, model CR-400), and expressed in values of $\mathrm{L}, \mathrm{a}^{*}$ and $\mathrm{b}^{*}$, which were used for chroma calculation (C $\left.=\left[a^{2}+b^{2}\right]^{1 / 2}\right)$. Color measurements were performed in 10 fruits for each repetition, with two readings per fruit, one in the equatorial region and the other in the basal region.

Total anthocyanin and flavonoid contents were measured according to the methodology described by Lees and Francis (1972), on samples of $10 \mathrm{~g}$ of fruit pulp homogenized in $50 \mathrm{~mL}$ of a solution containing $95 \%$ ethanol and $1.5 \mathrm{~N} \mathrm{HCl}(85: 15 \mathrm{v} / \mathrm{v})$. After $12 \mathrm{~h}$ in the dark at $4{ }^{\circ} \mathrm{C}$, a $2-\mathrm{mL}$ aliquot of this solution was used for the absorbance reading in a spectrophotometer at 535 and $374 \mathrm{~nm}$, respectively (Biochrom Libra S22). The results were expressed in mg. $100 \mathrm{~g}^{-1}$ of pulp. The antioxidant activity was determined by the FRAP (Ferric Reducing Antioxidant Potential) method, as described by Benzie and Strain (1996), and by free radical DPPH scavenging method (2,2-diphenyl-1-picrylhydrazyl), according to Brand-Williams et al. (1995). For FRAP determination, $10 \mathrm{~mL}$ of methanol were added to $0.10 \mathrm{~g}$ of ground pulp, previously subjected to an ultrasonic bath for $10 \mathrm{~min}$ and centrifugation at $6,000 \mathrm{rpm}$ for $10 \mathrm{~min}$ The assay was performed in cuvettes with the addition of $90 \mu \mathrm{L}$ of water, $30 \mu \mathrm{L}$ of the sample and $900 \mu \mathrm{L}$ of FRAP reagent. After 90 min, the absorbance was read at $594 \mathrm{~nm}$. For instrument calibration, methanol was used as "blank", while a 0.2 $\mathrm{mM} \mathrm{FeSO}_{4} 7 \cdot \mathrm{H}_{2} \mathrm{O}$ stock solution was used for the standard curve construction, being the results expressed in $\mu \mathrm{mol}$ $\mathrm{FeSO}_{4} 100 \mathrm{~g}^{-1}$ of pulp. For DPPH determination, $10 \mathrm{~mL}$ of ethanol were added to $0.10 \mathrm{~g}$ of ground pulp and were then submitted to $10 \mathrm{~min}$ of ultrasonic bath and $10 \mathrm{~min}$ of centrifugation at $6,000 \mathrm{rpm}$. Cuvettes were filled with 500 $\mu \mathrm{L}$ of the sample, $3000 \mu \mathrm{L}$ of ethanol and $300 \mu \mathrm{L}$ of DPPH reagent. Absorbance was read at $517 \mathrm{~nm}$, after a 30-min rest period. Calibration was performed with ethanol as "blank" and the antioxidant activity was expressed in \% of reduced DPPH and calculated as follows: $\%$ of reduced DPPH $=(($ Blank absorbance - Sample absorbance $) /($ Blank absorbance) $) * 100$.

The analyses were performed in the day of harvest and every 2 days, along 6 days. Data were submitted to analysis of variance, and the means were compared by the Tukey test $(P \leq 0.05)$ using the statistical software SAS 9.3.

Two days after harvest, the blueberries had a $3.74 \%$ fresh weight loss, which continuously evolved until the last storage day, when they were extremely shriveled and had more than 20\% initial mass loss, (Figure 1A), and were no longer attractive for fresh consumption. Such large weight loss probably occurred as a result of the non-refrigerated storage conditions, which could have led to the elevated fruit transpiration and respiration rates. Eum et al. (2013) also observed that 'Duke' and 'Bluetta' blueberries became improper for commercialization after 6 days of storage at room temperature $\left(20-25^{\circ} \mathrm{C}\right)$, with weight loss rates of $2.5 \%$ for 'Duke' and $4.0 \%$ for 'Bluetta' blueberries.

Luminosity and $b^{*}$ colorimetric variables of 'Snowchaser' blueberries skin did not vary throughout the storage period (Figures $1 \mathrm{~B}, 1 \mathrm{C}$ ). Hence, there was no darkening of the blueberries from their harvest to senescence, indicating that this cultivar does not have problems of skin color variation along a 6-day storage period at room temperature, probably for being this a non-climacteric fruit.

Between the second and the fourth day after harvest, there was a reduction in the $\mathrm{a}^{*}$ colorimetric variable values, from -1.00 to -1.65 (Figure $1 \mathrm{C}$ ), but 
this color variation was not associated with any visual change in blueberries skin color. Regarding chromaticity (C) values measured on fruit skin, there was a significant increase between the first and sixth days of storage, which is in agreement with higher pulp anthocyanin contents, once fruit skin chromaticity is also affected by pulp pigmentation (Figure $1 \mathrm{D})$.
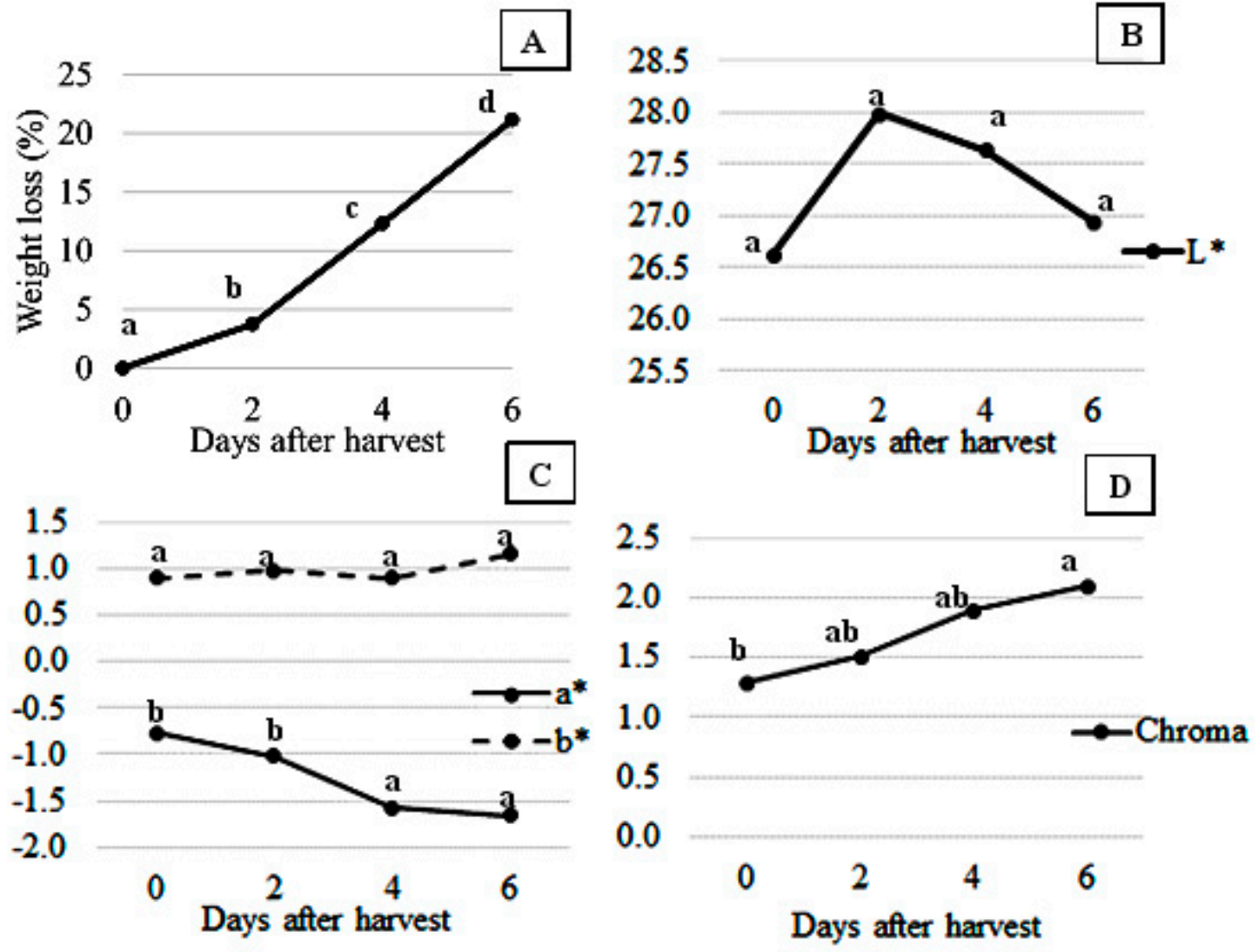

*Means followed by different letters significantly differ by the Tukey's test $(\mathrm{P}<0.05)$

Figure 1- Weight loss (A) and color parameters (B, C and D) of the 'Snowchaser' blueberry fruit during storage at room temperature.

Anthocyanin content in fruit pulp was elevated from the second day after harvest, reaching more than twice the initial content in the last day of analysis (Table 1). This expressive rise of blueberry pulp pigments may be probably caused by larger pigment biosynthesis and by a concentration effect because of the high fruit weight loss. The interconversion of organic acids by intensification of the shikimic acid pathway generates carbon skeletons that may be utilized for anthocyanin synthesis (KALT et al., 1999), a process that is boosted under storage conditions at room temperature, and might explain the observed steep increase of anthocyanins content. Fruits of the 'O'Neal' cultivar, which also belongs to the same group as 'Snowchaser', were stored at $0{ }^{\circ} \mathrm{C}$ and wrapped in a biodegradable film, and also presented a continuous rise in anthocyanin contents along a 15 day storage period (CHIABRANDO; GIACALONE, 2015). Rodrigues et al. (2011) also observed values of 69.97 and $162.85 \mathrm{mg}$ cyanidin-3-glucoside $100 \mathrm{~g}^{-1}$ in fruits of the 'Florida M' and 'Bluebelle' cultivars, respectively.

There was also an increase in flavonoid content of 'Snowchaser' blueberries, mainly recorded from the second to the fourth day of storage (Table 1), probably because flavonoid continued to be biosynthesized in the postharvest period. Maximum flavonoid contents of 'Snowchaser' blueberries were registered after 4 and 6 days of room temperature storage and reached 50.23 to $53.18 \mathrm{mg} 100 \mathrm{~g}^{-1}$. Bunea et al. (2011) observed flavonoid

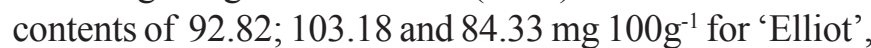
'Bluecrop' and 'Duke' blueberry fruits, respectively.

FRAP method revealed an increment in antioxidant activity between 4 to 6 days of storage at room temperature, which coincides with the rise in anthocyanin and flavonoid contents (Table 1). As the fruits employ antioxidants compounds against its senescence, there can be a decrease of this activity, with a recovery later. The DPPH determination did not indicate any difference in free radical scavenging activity along the postharvest period, with values varying from 47.79 to $57.31 \%$ (Table 1). These results indicated that, despite fruit senescence, there was no reduction of the antioxidant activity, which means that even in an advanced maturation stage, these fruits may bring benefits to consumers' health.

Schotsmans et al. (2007) also observed an increased antioxidant activity in 'Maru' and 'Centurion' blueberries stored at $20{ }^{\circ} \mathrm{C}$. For 'Elliot', 'Bluecrop' and 'Duke' blueberries, antioxidant activity values of 50.74, 60.39 and $33.03 \mu \mathrm{M} \mathrm{Fe}^{2+} \mathrm{g}^{-1}$ were obtained by the FRAP method, 
whereas by DPPH method the values were $43.48 ; 46.64$ and $29.96 \%$, respectively (BUNEA et al., 2011). Thus, when compared to other blueberry cultivars, 'Snowchaser' showed good performance, reaffirming its potential for fresh fruit market.
When stored at room temperature, 'Snowchaser' blueberries had a maximum conservation period of six days, mainly due to elevated fruit weight loss. The variety also exhibits a high potential regarding the fruit antioxidant capacity, and may be recommended for cultivation in Brazil in regions with low chilling incidence.

Table 1. Contents of anthocyanins, flavonoids and antioxidant activity of 'Snowchaser' blueberry fruits during storage at room temperature. Esalq/USP, Piracicaba/SP, Brazil, 2015.

\begin{tabular}{|c|c|c|c|c|}
\hline $\begin{array}{c}\text { Days After } \\
\text { Harvest }\end{array}$ & 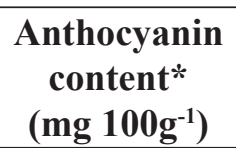 & 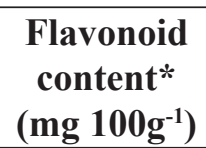 & $\begin{array}{c}\text { FRAP* } \\
(\mu \mathrm{mol} \\
\left.\text { FeSO }_{4} \mathbf{1 0 0 g}^{-1}\right)\end{array}$ & $\begin{array}{l}\text { DPPH* } \\
(\%)\end{array}$ \\
\hline $\mathbf{0}$ & $62.36 \mathrm{c}$ & $31.81 \mathrm{~b}$ & $39.50 \mathrm{ab}$ & $47.79 \mathrm{a}$ \\
\hline 2 & $68.85 \mathrm{c}$ & $36.94 \mathrm{~b}$ & $38.39 \mathrm{ab}$ & $49.79 \mathrm{a}$ \\
\hline 4 & $102.77 \mathrm{~b}$ & $50.23 \mathrm{a}$ & $36.59 \mathrm{~b}$ & $50.62 \mathrm{a}$ \\
\hline 6 & $141.67 \mathrm{a}$ & $53.18 \mathrm{a}$ & $50.23 \mathrm{a}$ & $57.31 \mathrm{a}$ \\
\hline
\end{tabular}

*Means followed by different letters in columns significantly differ by the Tukey's test $(P \leq 0.05)$.

\section{Acknowledgement}

To the University of São Paulo (Project 7106 - Benefit 18-1) for the financial support and to the grower Mr. Luis Milner, who provided the fruit for evaluation.

\section{References}

BENZIE, I.F.; STRAIN, J.J. The Ferric Reducing Ability of Plasma (FRAP) as a Measure of "Antioxidant Power": The FRAP Assay. Analytical Biochemistry, San Diego, v.239, p.70-76, 1996.

BRAND-WILLIAMS, W.; CUVELIER, M.E.; BERSET, C. Use of a free radical method to evaluate antioxidant activity. Food Science and Technology, Campinas, v.28, n.1, p.25-30, 1995.

BUNEA, A.; RUGINĂ, D.O.; PINTEA, A.M.; SCONŢA, Z.; BUNEA, C.; SOCACIU, C. Comparative polyphenolic content and antioxidant activities of some wild and cultivated blueberries from Romania. Notulae Botanicae Horti Agrobotanici Cluj-Napoca, Cluj-Napoca, v. 39, n.2, p. 70-76, 2011.

CANTUARIAS-AVILÉS, T.; SILVA, S.R.; MEDINA, R.B.; MORAES, A.F.G.; ALBERTI, M.F. Cultivo do mirtilo: atualizações e desempenho inicial de variedades de baixa exigência em frio no Estado de São Paulo. Revista Brasileira de Fruticultura, Jaboticabal, v.36, n.1, p.139-147, 2014.

CHIABRANDO, V.; GIACALONE, G. Anthocyanins, phenolics and antioxidant capacity after fresh storage of blueberry treated with edible coatings. International Journal of Food Sciences and Nutrition, London, v.66, n.3, p.248-253, 2015.
CONCENÇO, F.I.R.; STRINGHETA, P.C.; RAMOS, A.M.; OLIVEIRA, I.H.T.O. Blueberry : Functional Traits and Obtention of Bioactive Compounds. American Journal of Plant Sciences, Irvine, v. 5, n.18, p. 26332645, 2014.

EUM, H.L.; HONG, S.C.; CHUN, C.; SHIN, I.S.; LEE, B.Y.; KIM, H.K.; HONG, S.J. Influence of Temperature during Transport on Shelf-life Quality of Highbush Blueberries (Vaccinium corymbosum L. cvs. Bluetta, Duke). Horticulture, Environment, and Biotechnology, Iseo-Myeon, v. 54, n.2, p.128-133, 2013.

KALT, W.; FORNEY, C.F.; MARTIN, A.; PRIOR, R. Antioxidant capacity, vitamin C, phenolics, and anthocyanins after fresh storage of small fruits. Journal of Agriculture and Food Chemistry, Davis, v.47, n.11, p.4639-4644, 1999.

LEES, D.H.; FRANCIS, F.J. Standardization of pigment analyses in cranberries. Hortscience, Alexandria, v.7, n.1, p.83-84, 1972.

LIM, T.K. Vaccinium corymbosum. In: LIM, T.K. Edible medicinal and non-medicinal plants. Netherlands: Springer, 2012. p. 452-465.

LYRENE, P.M. Snowchaser' southern highbush blueberry. Florida Foundation Seed Producers. Patente USPP19503 P3, 25 nov. 2008.

PATEL, S. Blueberry as functional food and dietary supplement: the natural way to ensure holistic health. Mediterranean Journal of Nutrition and Metabolism, Milano, v.7, n.2, p.133-143, 2014. 
RODRIGUES, E.; POERNER, N.; ROCKENBACH, SCHOTSMANS, W.; MOLAN, A.; MACKAY, B. I.I.; GONZAGA, L.V.; MENDES, C.R.; FETT, R. Controlled atmosphere storage of rabbiteye blueberries Phenolic compounds and antioxidant activity of blueberry enhances postharvest quality aspects. Postharvest cultivars grown in Brazil. Food Science and Technology, Biology and Technology, Amsterdam, v.44, n.3, p.277Campinas, v.31, n.4, p.911-917, 2011. 285, 2007. 